
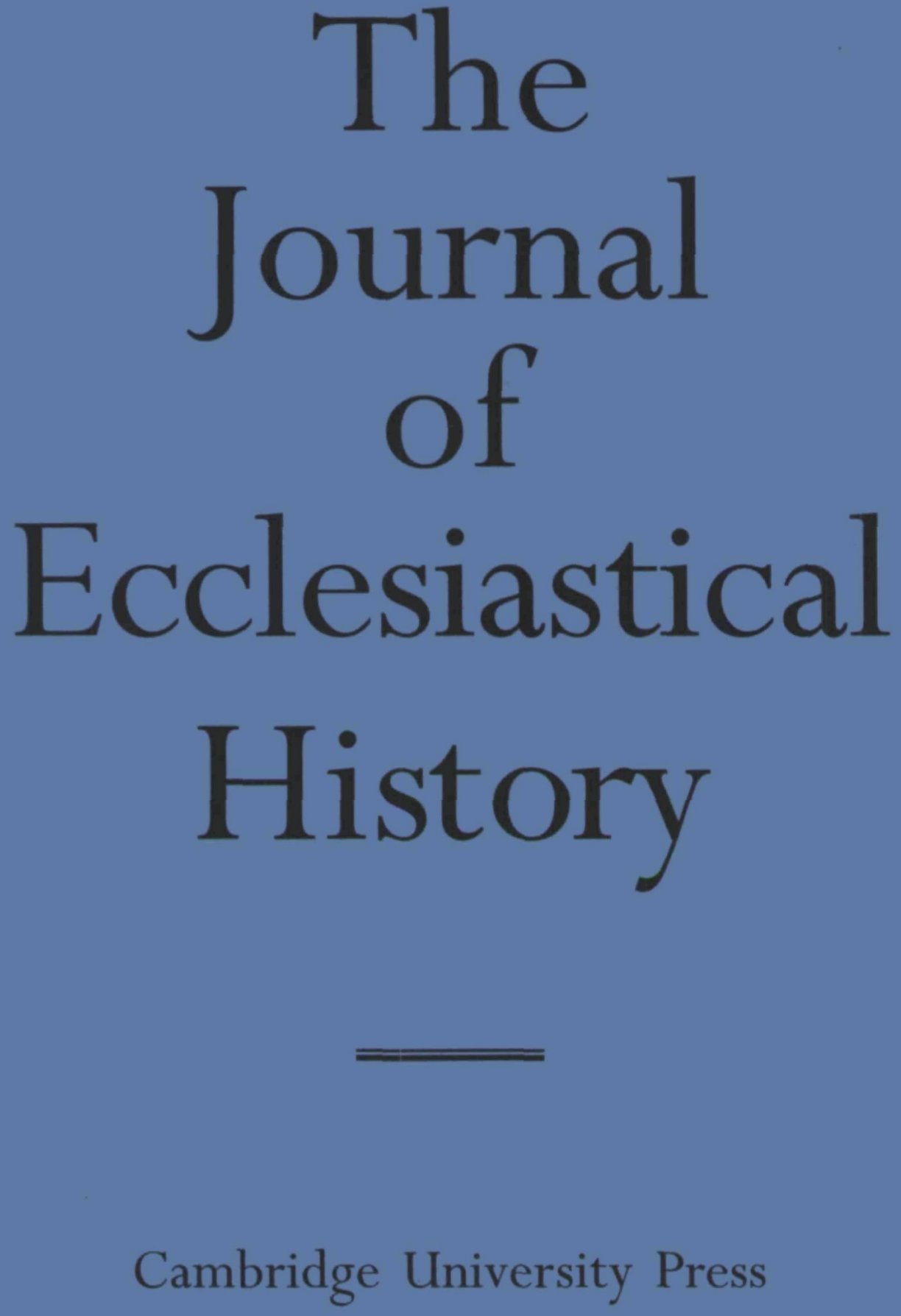
Editors

Martin Brett and Diarmaid MacCulloch

Assistant Editor

Christine Linehan

\section{Advisory Editorial Board}

Richard Carwardine, University of Sheffield

W. O. Chadwick, Seluynn College, Cambridge

Patrick Collinson, Trinity College, Cambridge

R. B. Dobson, Christ's College, Cambridge

W. H. C. Frend, University of Glasgow

P. A. Linehan, St. John's College, Cambridge
Hugh McLeod, University of Bimingham

Janet Nelson, King's College, London

D. M. Nicol, Cambridge

J. S. Riley-Smith, Emmanuel College, Cambridge

W. J. Sheils, University of $Y_{\text {ork }}$

W. R. Ward, University of Durham

() Cambridge University Press 1995

Contributions and books for review should be addressed to the Editors, Joumal of Ecclesiastical History, Robinson College, Cambridge CB3 gAN. A copy of the Journal's style sheet will be sent to intending contributors on application to the Editors.

The Journal of Ecclesiastical History (ISSN $0022-0469$ ) is published quarterly by Cambridge University Press, The Edinburgh Building, Shaftesbury Road, Cambridge CB2 2RU and 40 West 2oth Street, New York, NY IoolI-4211. Four parts form a volume.

The subscription price (excluding VAT) of volume 46, 1995 (which includes postage) is $\AA_{193}$ (US $\$ 169$ in the USA, Canada and Mexico); for individuals ordering direct from the publisher and certifying that the journal is for their personal use it is $£ 49$ (US $\$ 89$ in the USA, Canada and Mexico). Single parts cost $£_{24}$ net (US \$44 in USA, Canada and Mexico) each plus postage. EU subscribers (outside the UK) who are not registered for VAT should add VAT at their country's rate. VAT registered subscribers should provide their VAT registration number. Japanese prices for institutions (including ASP delivery) are available from Kinokuniya Company Ltd, P.O. Box 55, Chitose, Tokyo 156, Japan.

Second class postage paid at New York, NY, and at additional mailing offices. POSTMASTER: send address changes in USA, Canada and Mexico to The Joumal of Ecclesiastical History, Cambridge University Press, I1 Midland Avenue, Port Chester, New York, NY 10573-4930.

Orders, which must be accompanied by payment, may be sent to a bookseller or to the publishers (in the USA, Canada and Mexico to the New York address). Enquiries about advertising should be sent to the publishers.

\section{Copying}

This journal is registered with the Copyright Clearance Center, 222 Rosewood Drive, Danvers, MA org23. Organisations in the USA who are also registered with C.C.C. may therefore copy material (beyond the limits permitted by sections 107 and 108 of US copyright law) subject to payment to C.C.C. of the per-copy fee of $\$ 7.50$. This consent does not extend to multiple copying for promotional or commercial purposes. Code o022-0469/95 \$7.50+\$o.10. Organisations authorised by the Copyright Licensing Agency may also copy material subject to the usual conditions.

ISI Tear Sheet Service, 3501 Market Street, Philadelphia, Pennsylvania 19104, USA, is authorised to supply single copies of separate articles for private use only.

For all other use, permission should be sought from Cambridge or the American Branch of Cambridge Ulished online by Cambrity Press. 